\title{
Decentralised Energy Systems and Associated Policy Mechanisms-A Review of Africa
}

\author{
Shadreck M. Situmbeko \\ Department of Industrial Design and Technology, University of Botswana, Gaborone, Botswana \\ Email: situmbeko@mopipi.ub.bw,ssitumbeko@yahoo.com
}

How to cite this paper: Situmbeko, S.M. (2017) Decentralised Energy Systems and Associated Policy Mechanisms-A Review of Africa. Journal of Sustainable Bioenergy Systems, 7, 98-116. https://doi.org/10.4236/jsbs.2017.73008

Received: July 21, 2017

Accepted: September 9, 2017

Published: September 12, 2017

Copyright $\odot 2017$ by author and Scientific Research Publishing Inc. This work is licensed under the Creative Commons Attribution International License (CC BY 4.0).

http://creativecommons.org/licenses/by/4.0/ (c) (i) Open Access

\begin{abstract}
Decentralised energy (DE), also known as distributed energy, refers to power generation and energy storage systems located at or near the point of use; and may also be connected to a local distribution network system or to a high voltage transmission system either directly or through a local distribution network system. It is generated or stored by a variety of small devices commonly referred to as distributed energy resources (DER); the definition also extends to include stand-alone systems completely isolated from the public networks. The contribution made by independent power producers (IPP's) through deployment of DER in the African energy market is critical to fast-tracking the deployment of renewables, diversification of the energy mix and enhancing access to modern and clean energy. There is need to develop policy mechanisms aimed at enhancing the current positive drive in the energy market; and this has been observed to be a driving factor in countries which have developed appropriate policy strategies. This paper presents the concept of DE in detail and how it could complement efforts to addressing the current energy crises in Southern Africa; it also looks at policy developments in Africa and presents the scenarios in the two southern African countries of South Africa and Botswana. The research is based on an extensive review of literature on the subject matter, consultations with stakeholders as well as feedback from the Learning Network for Sustainable Energy Systems (LeNSes) workshops.
\end{abstract}

\section{Keywords}

Decentralised Energy, Distributed Energy Resources, Renewables, Independent Power Producers, Energy Policy

\section{Introduction}

$\mathrm{DE}$ technologies include the full array of renewables suitable for deployment on 
local networks such as photovoltaics, biogas and biomass cogeneration, and geothermal, wind, wave, tidal and small-scale hydroelectric power. Cogeneration through "combined heat and power" (CHP) and trigeneration through "combined cooling, heat and power" (CCHP) are also considered as distributed energy technologies.

DER deployment has experienced steady growth over the years while more and more power is now being provided by IPP's. Benefits of DE include low transmission and distribution costs, improved accessibility, improved energy efficiency, security and reliability, as well as a reduction in environmental impact. The challenges to full-scale adoption of DE include political, legislative, finance and economic, as well as technical barriers.

Figure 1 shows a schematic representation of the range of technologies used for distributed generation.

The number of countries implementing policy measures and targets aimed at improved distributed energy deployment has been observed to be on the increase, especially regarding renewable energy sources; there is also an increase in the diversity of these policies. Table 1 shows a global coverage of regions with renewable energy policies in the years 2004, 2013 and 2014.

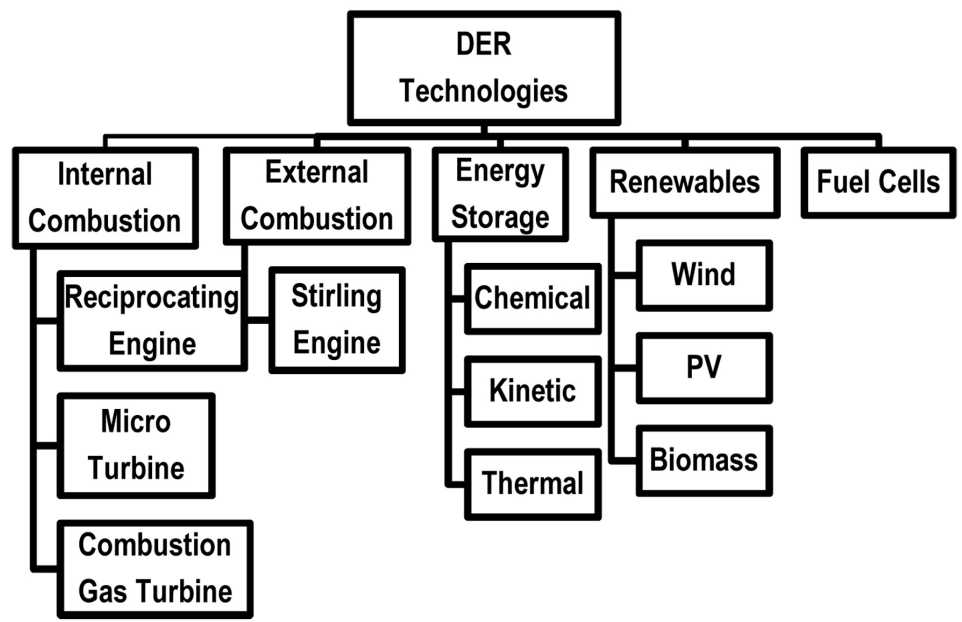

Figure 1. DER Technologies [1].

Table 1. Global policy development coverage for 2004, 2013 and 2014 [2].

\begin{tabular}{|c|c|c|c|}
\hline Policies & Start 2004 & 2013 & 2014 \\
\hline Countries with policy targets & 48 & 144 & 164 \\
\hline States/provinces/countries with feed-in policies & 34 & 106 & 108 \\
\hline States/provinces/countries with RPS/quota policies & 11 & 99 & 98 \\
\hline $\begin{array}{l}\text { Countries with tendering/public } \\
\text { competitive bidding }\end{array}$ & $\mathrm{n} / \mathrm{a}$ & 55 & 60 \\
\hline Countries with heat obligation/mandate & $\mathrm{n} / \mathrm{a}$ & 19 & 21 \\
\hline States/provinces/countries with biofuels mandates & 10 & 63 & 64 \\
\hline
\end{tabular}




\section{Distributed Energy Technologies}

Table 2 lists the main characteristics of some distributed energy technologies. These are discussed in brief in the subsections that follow.

Reciprocating Engines: reciprocating engines are a mature technology that is largely proliferated mainly due to their lower capital investment costs, fast startup capabilities and higher energy efficiencies when combined with heat recovery systems. Most reciprocating engines run either on fuel or natural gas with an

Table 2. Main characteristics of some distributed energy technologies [3].

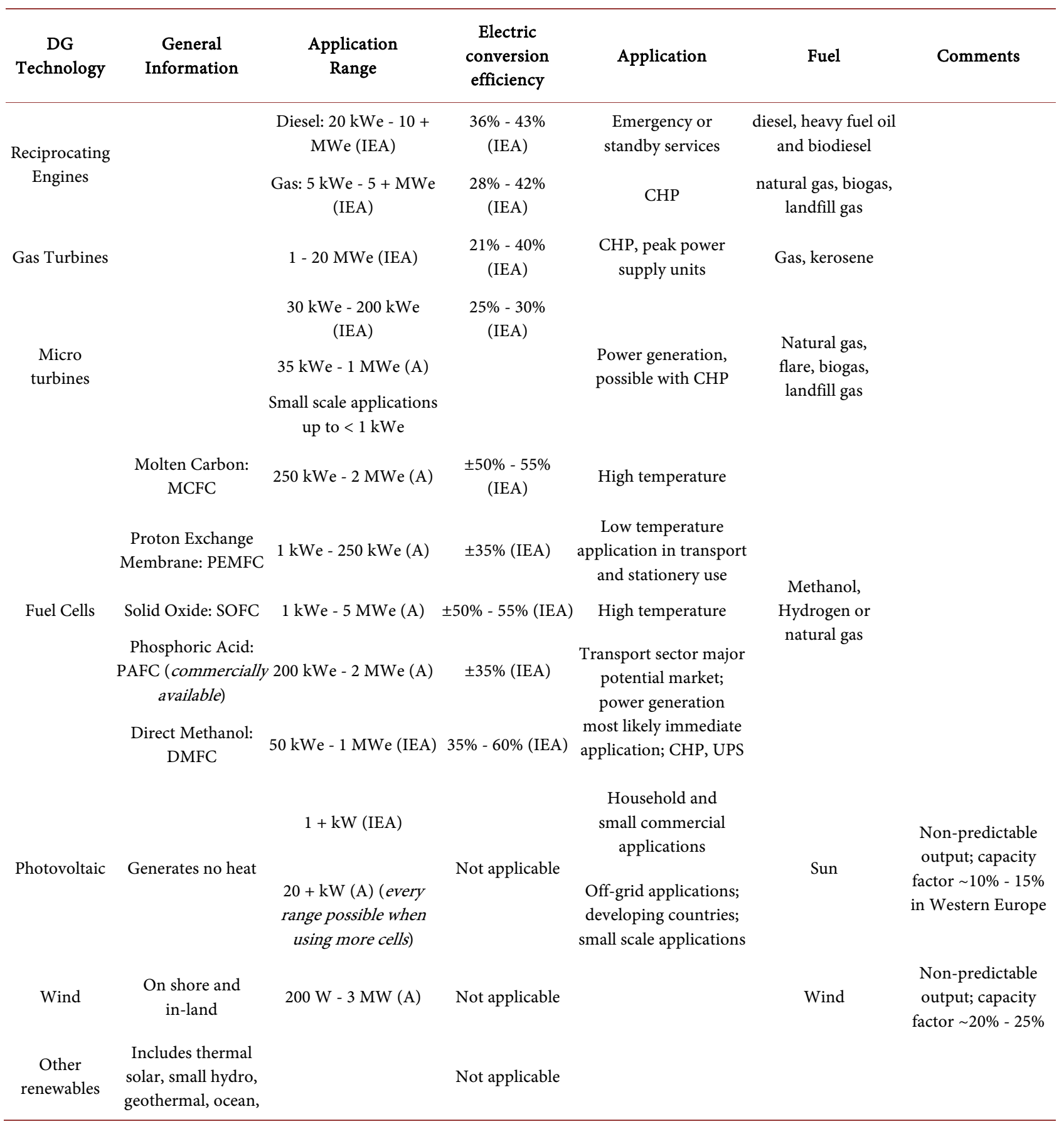


increasing number of engines running on biogas produced from biomass and landfill waste. Most of the reciprocating engines are used as back-up or stand-by generators; some are used as peaking generators and as continuous generators. Reciprocating engines, however, do not perform well in terms of noise, maintenance and emissions.

Gas Turbines: gas turbines are widely used for electricity generation. They mostly run on natural gas and have lower emission levels. They are widely used as continuous generators; with some being used as standby generators and peaking generators. Gas turbines are widely used in cogeneration.

Micro-turbines: the design and operation of micro-turbines is basically the same as that of gas turbines but have lower capacities and higher operating speeds.

Fuel cells: instead of converting mechanical energy into electrical energy, fuel cells are built to convert chemical energy of a fuel into electricity; and usually either natural gas or hydrogen is used as fuel. Fuel cells continue to be a major field of research and considerable effort is put in cutting down capital costs and improving efficiency which are the two main drawbacks to this technology.

Renewable sources: renewables have been utilised as distributed energy resources; renewable energies range from photovoltaics, wind, thermal energy etc. These sources only qualify as distributed generation if they satisfy the definition criteria. Distributed generation is thus not identical as renewable energy. For instance, offshore wind farms are not considered as "true" distributed generation.

Cogeneration and Trigeneration: cogeneration basically refers to combined heat and power (CHP) and is particularly applicable to steam power plants and natural gas-fired fuel cells, micro-turbines or reciprocating engines located close to industries that require process heat or residential areas that require space heating and water heating; in which case the waste heat from the power plant, as steam or hot exhaust, is used to provide the heating and thus raise the plant thermal efficiency in some instances to around $90 \%$ from about $40 \%$ associated with thermal power plants. Trigeneration or combined cooling, heat and power (CCHP) incorporates thermal absorption cooling to the CHP technology.

Storage: a distributed energy resource is not limited to electricity generation but may also include a device to store distributed energy. Distributed energy storage systems (DESS) applications include numerous types of battery, pumped hydro, compressed air, and thermal energy storage.

In addition to the technologies listed in the forgoing sections, are interface or interconnection technologies; these consist of both hardware and software equipment that makes up the physical link (or electrical connection) between distributed energy resource and the outside electrical power system (usually the local electric grid); and it can also include monitoring, control, metering, and dispatch of the distributed energy resource unit. They include inverters, transformers, power meters, transfer switches, and information and telecommunication technology. 


\section{Benefits of Decentralised Energy}

A number of benefits linked with a change from a centralised to a decentralised energy system can be identified and some are listed below:

\subsection{Security and Reliability}

With the persistence load shedding affecting the whole sub-region it makes sense at least in the short term to encourage small businesses and individuals to invest in energy generation either for own use or for distribution to other users having energy deficits. This will improve security and reliability of energy availability and supply in terms of:

- Back up generation: the use of distributed generation as backup or standby supply will prevent operational failures during peak hours or when there are network problems; in fact backup generators have been installed at critical locations such as hospitals and shopping malls; and increasingly many small businesses are investing in backup generators.

- Fuel diversity: the fact that distributed generators use the energy that is optimally available to them leads to a fuel diversity which in turn helps mitigate higher fuel prices, diminishing fossil fuel resources, and variations in whether and climatic patterns affecting wind, solar, hydro and oceanic energy resources, such as in the case of a river supplying a hydro-power station drying up. Distributed generation also taps into previously unused energy resources such as waste heat and landfill biogas.

\subsection{Rural Electrification}

It is now generally agreed that access to modern and clean energy spurs economic development and improves the standards of living. To date most Sub-Saharan African countries have electrifications levels below 30\%; this energy poverty has far reaching impact on key social issues such as primary healthcare and education. Due to the large capital expenditures required to connect remote areas owing to the vast distances to be covered by overhead lines to the centralised power systems, connecting remote areas with small consumption levels has proven uneconomical. In most of these countries the electricity transmission and distribution infrastructure remains underdeveloped and quite often suffers damage due to aging and vandalism. The situation is also worsened by the higher transmission and distribution losses as they tend to increase with the distance covered. Distributed generation as stand-alone or mini-grids often proves more economical. A number of government and foreign aid organisations programmes have tended to rely on distributed energy resources in their efforts to bringing modern and clean energy to peri-urban and rural areas in the form of photovoltaics, solar water heating and cooking, biogas digesters and wind pumps and generators [4].

\subsection{Environmental Impact}

Traditionally most centralised energy systems are based on fossil fuel (coal, oil, 
natural gas) power stations and are thus associated with large green-house gases emissions. Distributed generation can mitigate the impact in terms of avoidance of emissions associated with transmission and distribution losses, increasing of thermal efficiencies through cogeneration and trigeneration, and through distributed renewable energy.

\subsection{Investment in Transmission and Distribution Networks}

Adopting distributed energy systems also reduces the investments required for transmission and distribution infrastructure; the cost for transmission infrastructure can vary between $4 \%-15 \%$ of the total cost and between $27 \%-34 \%$ for the distribution infrastructure [5]. Distributed generation can be used as a way to bypass the transmission and distribution networks.

\subsection{Transmission and Distribution Costs}

Transmission and distribution costs account for up to $30 \%$ of the cost of delivered electricity on average; the lowest cost being attained by industrial clients receiving electricity at high to medium voltages and the highest cost by small customers receiving electricity from the distribution network at lower voltages. The higher costs for transmission and distribution are mainly a result of losses made up of:

- Line losses: these are energy losses in the transmission and distribution lines mainly due to line heating, the Joule effect, and for very high voltage, corona discharge losses, which are losses due to the ionization of a fluid or gas surrounding a conductor that is electrically charged. The ratio for developing countries is reported to vary between $11.6 \%$ and $20.7 \%$ [5].

- Unaccounted for electricity: is attributed to energy theft and distribution loss deviations, as well as errors arising from meter measurements, power flow modelling, and statistical load profiles. Transmission over vast distances is prone to illegal connections as can be seen in the image, in Figure 2, of an

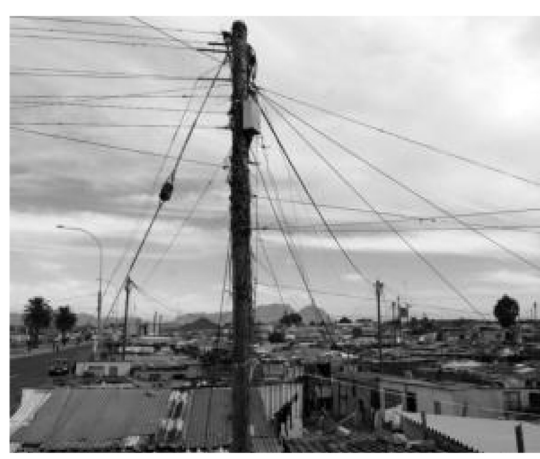

(a)

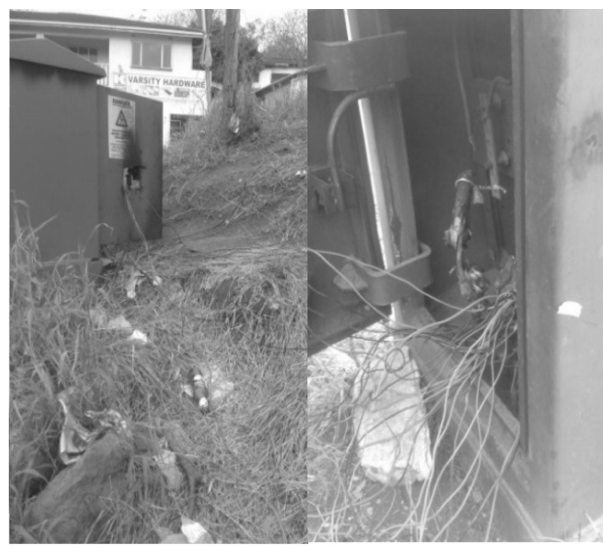

(b)

Figure 2. Illegal power connections in Durban. (a) connections to homes [7]. (b) connections from a transformer Pictures by: K. Mubiana, Durban. 
informal settlement in Durban, South Africa; residents of informal settlements illegally tap into the electricity supply [6].

- Conversion losses: these are losses associated with the changing of the characteristics of the power flow to fit the specifications of the network, such as magnetic losses in transformers for stepping up or down of the voltage or in inverters for conversion from alternating current (AC) to direct current (DC) or vice versa; or conversion of the waveform from sinusoidal waveform to a different waveform such as triangular or square wave.

\subsection{Energy Efficiency}

Figure 3 shows electricity generation efficiencies for different technologies. It can clearly be seen that fossil powered power plants have about $40 \%-50 \%$ conversion efficiencies. These figures can be raised to about $80 \%-90 \%$ through combined heat and power (CHP), or combined cooling, heat and power (CCHP). Figure 4 shows a schematic representation of a trigeneration plant. Both CHP and CCHP especially on a small to medium size scale are considered distributed energy resources.

\subsection{Electricity Deregulation and Cost Control}

Adoption of distributed energy systems promotes deregulation of the electricity market as it entails the involvement of many players; this in turn leads to flexibility

\section{Electricity Generation Efficiencies (\%)}

$\begin{array}{lllllllllll}0 & 10 & 20 & 30 & 40 & 50 & 60 & 70 & 80 & 90 & 100\end{array}$

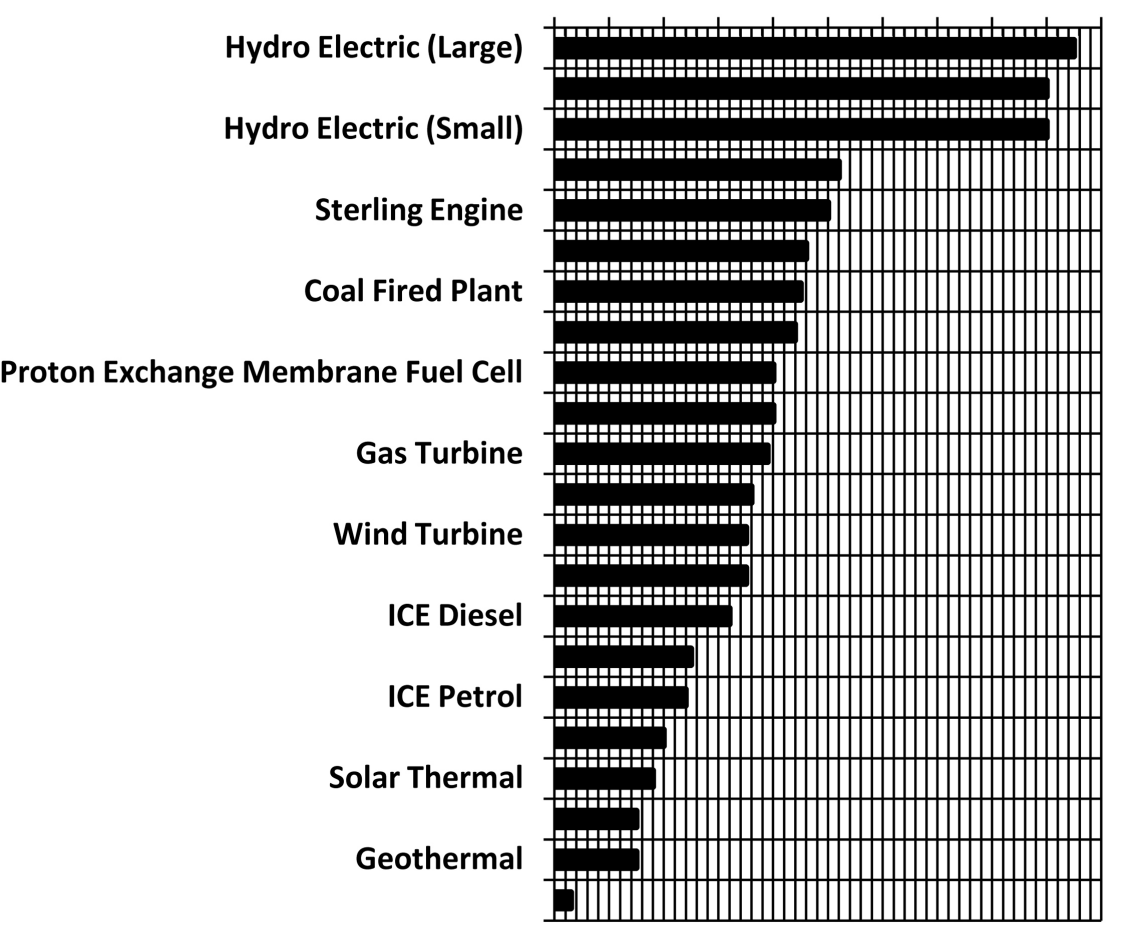

Figure 3. Electricity generation efficiencies for different technologies [8]. 


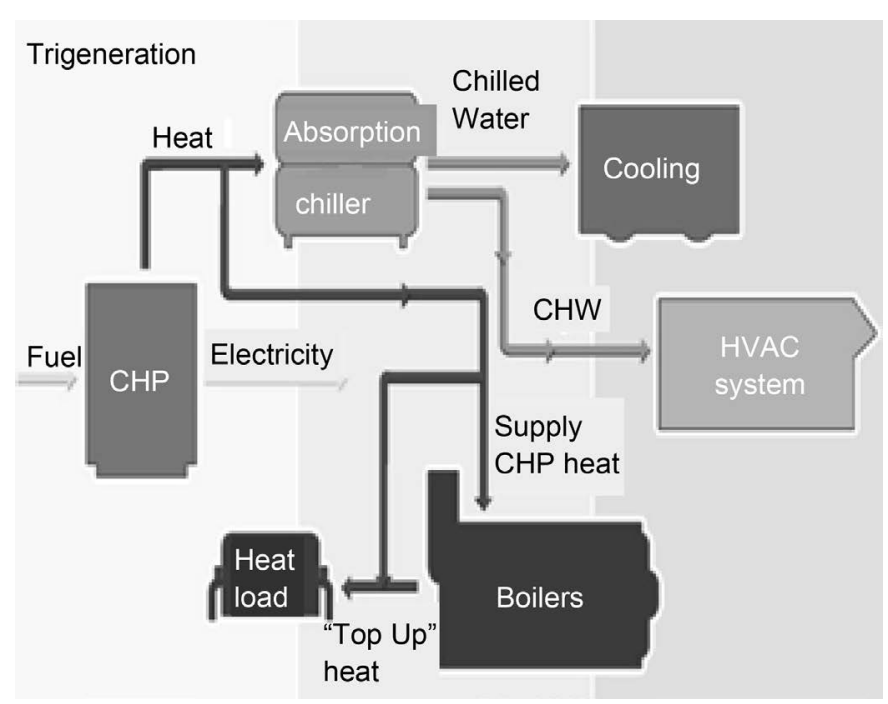

Figure 4. Trigeneration plant schematic representation [9].

in the market with potential benefits of efficient and reliable delivery, competitive pricing, and employment creation. Deregulation has brought with it the new concept of "prosumer", - both producer and consumer, whereby consumers can also take on the role of producers.

\section{Challenges to Decentralised Energy}

Challenges to widespread and full adoption of distributed energy systems can be categorised as technical, market and regulatory.

\subsection{Technical Challenges}

Capacity: this is more applicable to grid-connected distributed energy systems; the existing transmission and distribution infrastructure capacity has been developed on a centralised, unidirectional flow model; adding distributed generators, as in Figure 5, may require certain sections of the existing network to handle larger amounts of power than their designed capacity. Other existing equipment such as transformers may not have the capability to handle bidirectional power flow and voltage conversion.

Voltage rise effect: below a certain threshold level distributed energy integration tends to have a positive effect in stabilising the network voltage by balancing out the voltage loss due to resistance in the cables; however, above that threshold which results from a higher number or more dense integration of distributed energy units, the effect is detrimental as it leads to a voltage rise above the required network specifications.

Power quality: power quality refers to the fitness of electric power to consumer devices; it is a set of values of parameters, such as: continuity of service, variation in voltage magnitude, transient voltages and currents, and harmonic content in the waveforms for AC power. Integration of distributed energy resources can cause regulation problems such as low voltage due to distributed 


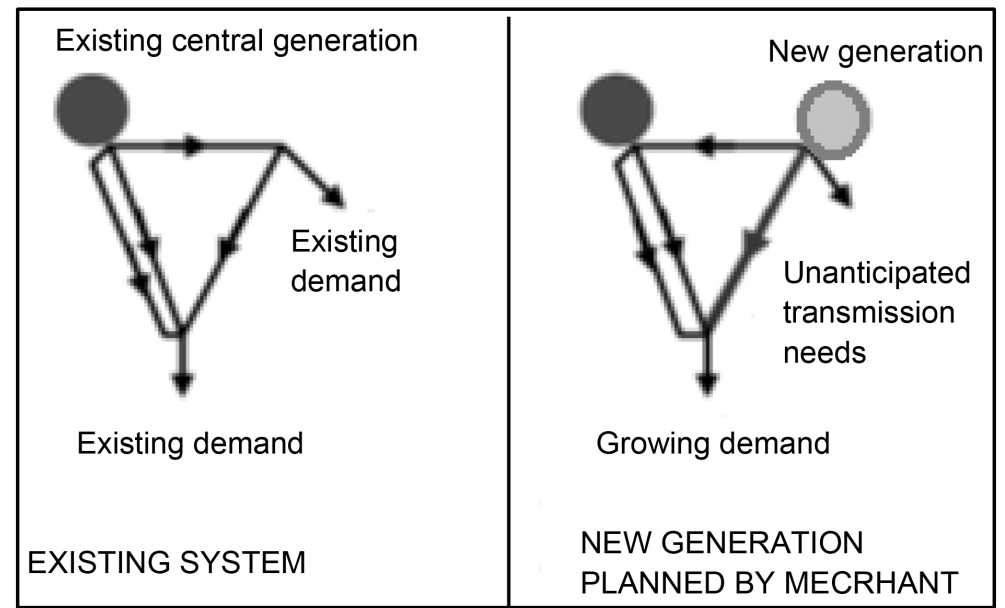

Figure 5. Increased load on network with distributed generation [10].

energy resource placed just downstream of a voltage regulator with line-drop compensation, or high voltage caused by reverse power flow from a distributed energy resource; also in cases where the distributed energy resource has varying output, the case with some renewable energy sources with fluctuating power such as PV, solar thermal, wind and oceanic, interaction of the distributed energy resource with regulation equipment may change the system voltage or current flows away from the required network specifications.

Protection: protection is one of the most critical technical challenges as it has a bearing on safety of people and equipment. Most conventional grid networks are designed as radial, unidirectional (with power flow from the source to the customers) systems based on the assumption of "no generation" on the downstream of the networks. This means the protection systems lack capacity to detect overcurrents, overvoltages, and undetectable islanding resulting from the integration of distributed generation; islanding occurs when part of the network is still operating with the distributed generators delivering electricity to customers while the rest of the network has been disconnected. It can be useful to operate the network in such a way to ensure steady supply of consumers with critical need for electricity or ensure that the majority of the network is still operating while a section is under maintenance. The main issue comes from undetected islanding as network operators might undertake repair work and thus incur significant risk for staff members.

Stability: Voltage and current transients-short term abnormal voltage or current oscillation may occur as distributed generators are switched on or off. The result of these oscillations can have a destabilizing effect on the network. Problems may also arise with large, fluctuating distributed energy resources such as wind and solar energy on the voltage stability of the system.

\subsection{Market and Regulatory Challenges}

Market Information and Data: to effectively integrate DER there is need for proper sharing and generation of market data between large power utilities, 
small to medium scale distributed generators and consumers, both industries and individuals.

Investment Capital: accessing finance may prove problematic especially when dealing with newer investment markets such as distributed energy resources and technologies that have not gained commercial maturity; such is the case with most renewable energy resources.

Costs and Incentives Resolution: integration of distributed generators in the distribution and transmission networks alters the commercial mechanisms of the power system in terms of both investment, and maintenance and operational costs and financial compensation; these issues require being resolved before full scale integration can be attained.

Long-term Market Outlook: lack of long-term market assurance to provide financial certainty to support investment and allow long term planning for recovery of development and operating costs.

\section{Policy Development}

In order to address some of the challenges raised in the foregoing section there is need to develop a supportive policy framework. There are also some newer developments in the energy market that require a change in policies governing the energy sector. Some of these factors are:

- Shift in the business models; and

- Changes in the energy mix.

These are discussed in detail in subsections 5.1 and 5.2; whilst 5.3 looks at issues that needs to be addressed by the policy framework.

\subsection{Shift in the Business Models}

The shift in the business models is mainly due to the trend to shift towards competition models and the admission of distributed energy resources in the energy systems.

Figure 6 shows the basic layout of an electricity system comprising a wholesale subsector in the form of generation and transmission, and a retail subsector in the form of a distribution network.

The traditional business model is mainly based on the concept of vertically-integrated power utility usually a national parastatal running a monopoly. This type of model is represented in Figure 7.

A move towards competition means adopting one of the following three business models:

- Liberalized generation only (most common model in Africa);

- Liberalized generation and transmission; or

- Liberalized generation, transmission and distribution

These competition models are presented in Figures 8-10 respectively.

Figure 11 shows the integration of distributed energy resources in the energy mixgiving rise to the concept of a prosumer, entities in the main stream energy 


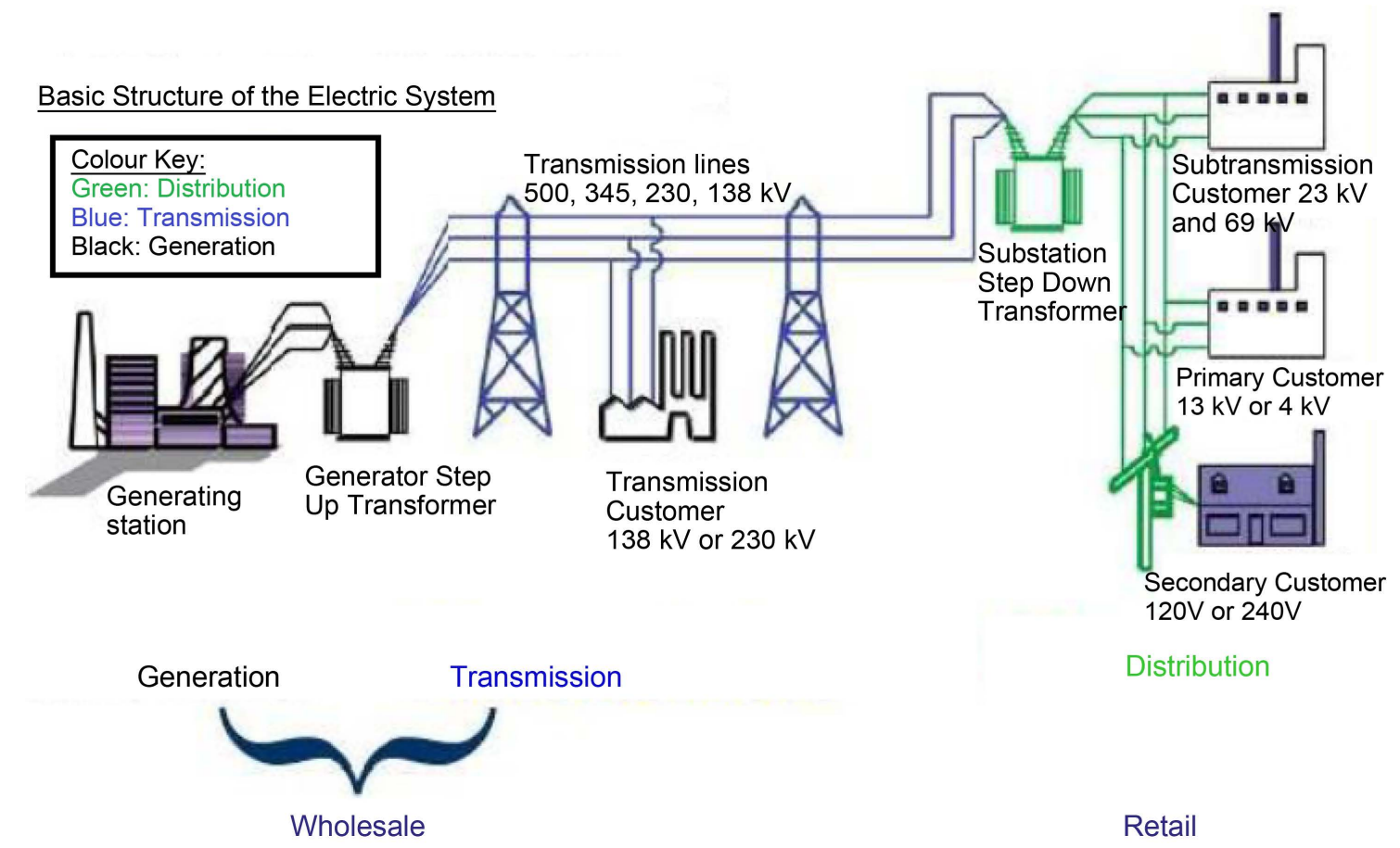

Figure 6. Basic electricity system [11].

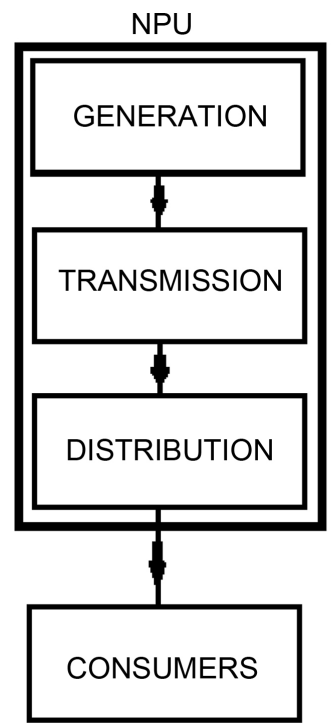

Monopolistic control of generation, transmission

\& distributio

Figure 7. Traditional vertically-integrated power utility [11].

system acting as both producers and consumers.

\subsection{Changes in the Energy Mix}

Increasingly the energy sources are getting more and more diversified with unprecedented increases in renewable energy entrants. In 2014 alone, about 58.5\% of net additional global power capacity came from renewables and by the yearend it is estimated that $27.7 \%$ of the global power generating capacity comprised of renewables, projected to contribute an estimated $22.8 \%$ to global electricity; 


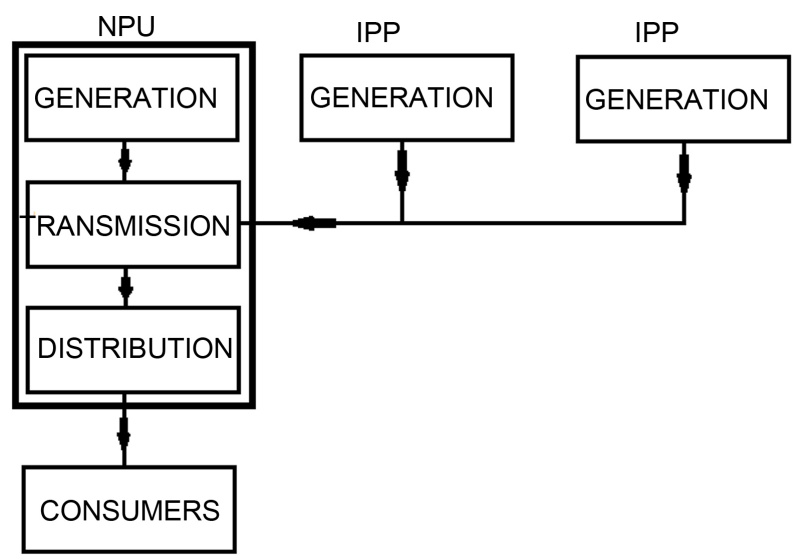

Figure 8. Generation competition only. (IPP = Independent power producer, NPU $=$ National power utility).

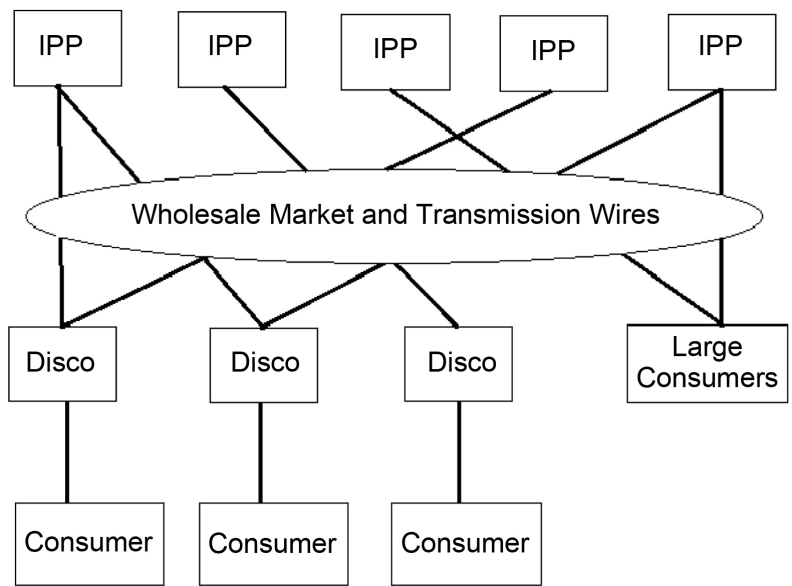

Figure 9. Wholesale competition only [11]. (DisCo = Distribution Company).

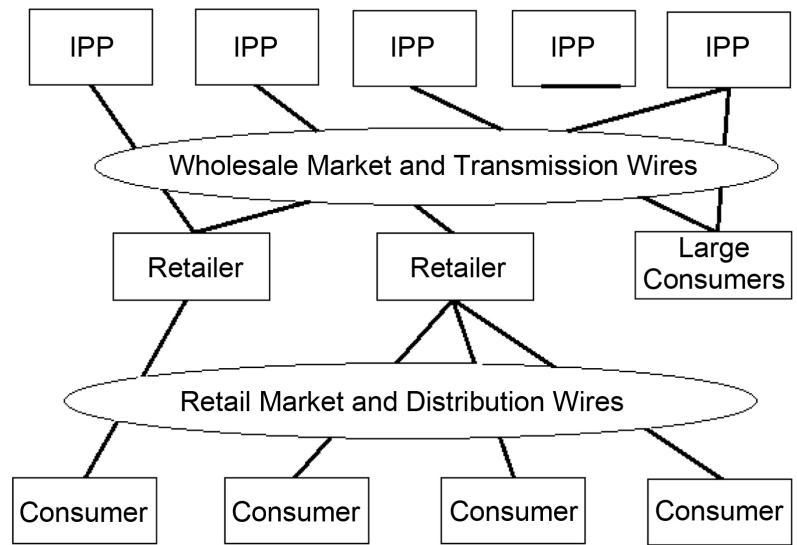

Figure 10. Both wholesale and retail competition [11].

wind, solar PV, and hydropower taking centre-stage in the market. These developments have compelled policy makers in some jurisdictions to stipulate that utilities update their business models and grid infrastructure [2]. 


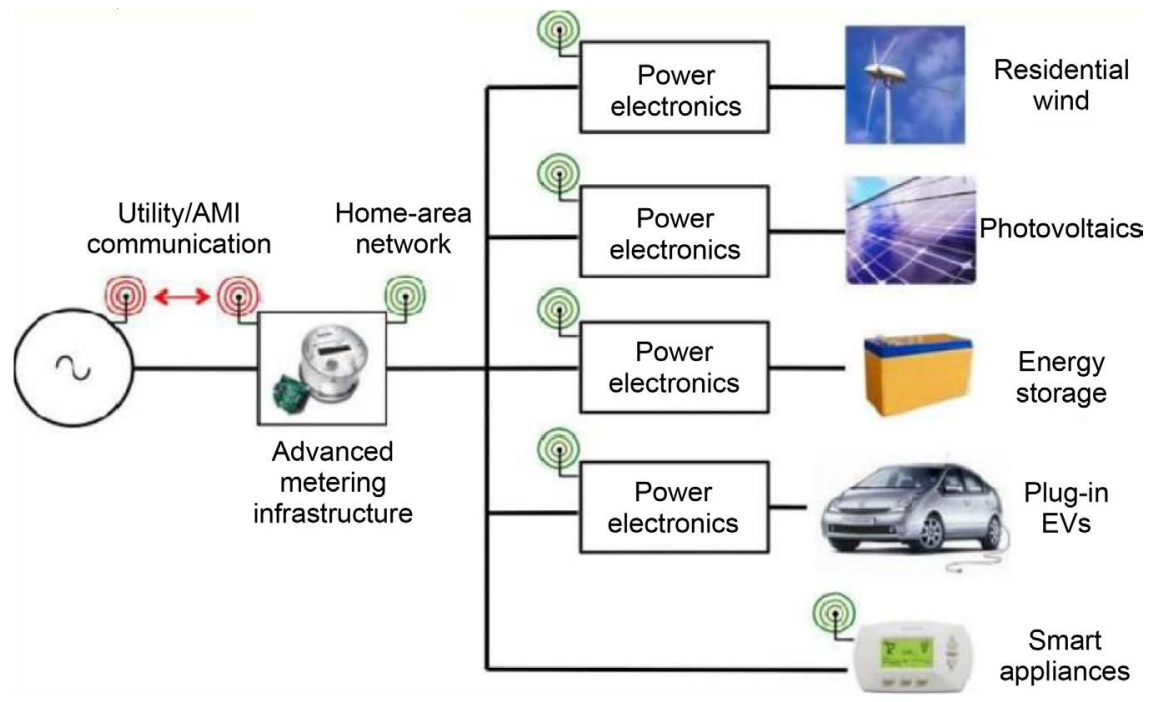

Figure 11. Consumer-owned distributed energy resource possibilities [11].

\subsection{Issues Requiring Policy and Regulatory Intervention [12]}

- Financial \& Regulatory: Well defined policies are necessary to assure an impartial and transparent distribution of costs and incentives among the various stakeholders. Key to this is that costs should be shouldered by market players that cause them whilst incentives should be based on clearly defined objectives and regularly reviewed in conformity with the market factors.

- Market Development \& Deployment: There is a need to establish a regulatory body that will ensure a fair, equitable and non-prejudiced energy market. It is also necessary to develop just interconnection rules and data sharing mechanisms to ensure a level stage that accommodates both larger utilities and non-large producers.

- Consumer Issues: Consumer protection policies need to be developed so as to provide a clear platform for settling disputes and complaints by all stakeholders. Such policies should be regularly reviewed and amended accordingly; they should also include standards for data protection, access, and disclosure.

- Safety, Reliability \& System Planning: The shift from traditional centralised power systems to distributed power systems necessitates a review of regulations, standards, procedures and practices for the planning, operation and reliability of transmission and distribution networks. This is particularly so due the changes in the loading and the bidirectional flow of distributed systems thus requiring equipment and operational modifications but more importantly to address newer requirement for the safety and protection of stakeholders and their assets.

\section{Southern Africa}

\subsection{Distributed Energy Resources in Southern Africa}

Power generation and transmission in the Southern African sub-region can be best represented by the Southern African Power Pool (SAPP) network map as 
shown in Figure 12. Table 3 shows the future proposed and planned energy projects.

The discussion on distributed energy resources in the sub-region would normally centre on stand-alone systems for remote locations and usually through government rural electrification and improvement to clean and modern energy-access programmes; but also through mini-grids powering certain institutions and residences. Apart from South Africa, where there is now a move towards promoting private energy generation mainly from renewable energy resources, there is low grid-integration of distributed generation. This is mainly

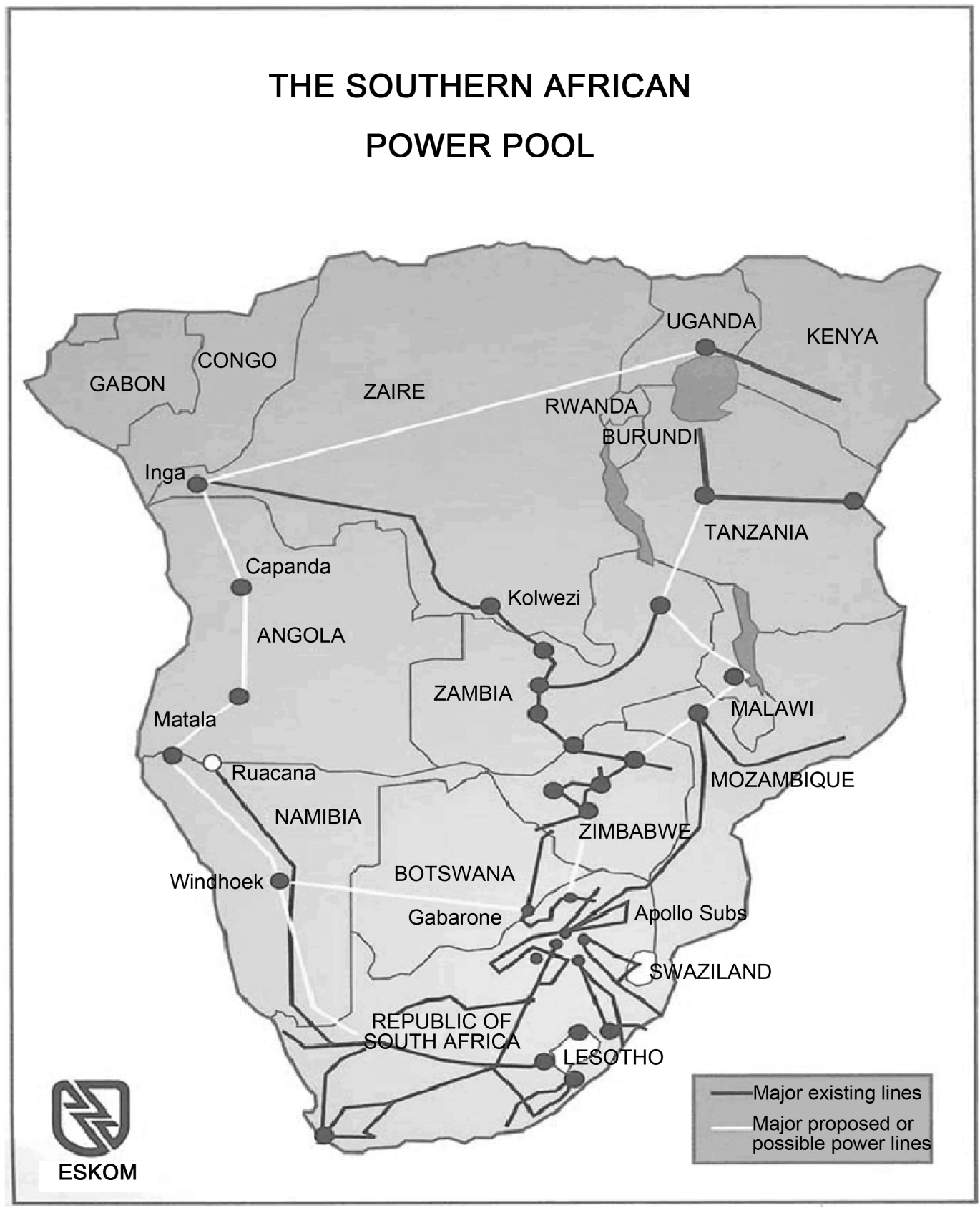

Figure 12. Southern African Power Pool (SAPP) network [13]. 
Table 3. ${ }^{\star}$ Future projects power generating capacity (MW) [15] (in parenthesis, sum of committed projects).

\begin{tabular}{|c|c|c|c|c|c|c|c|c|}
\hline MW & Oil & Coal & Gas & Hydro & Biomass & Wind & Solar & Total \\
\hline Angola & $\begin{array}{c}288 \\
(148)\end{array}$ & & & $\begin{array}{c}6735 \\
(1225)\end{array}$ & & & & $\begin{array}{c}7023 \\
(1373)\end{array}$ \\
\hline Botswana & & $\begin{array}{c}3630 \\
(1200)\end{array}$ & & & & & & $\begin{array}{c}3630 \\
(1200)\end{array}$ \\
\hline DRC & & & & 20240 & & & & 20240 \\
\hline Lesotho & & & & $\begin{array}{c}190 \\
(110)\end{array}$ & & 65 & & $\begin{array}{c}255 \\
(110)\end{array}$ \\
\hline Malawi & & & & 614 & $\begin{array}{c}18 \\
(18)\end{array}$ & & & $\begin{array}{l}632 \\
(18)\end{array}$ \\
\hline Mozambique & & $\begin{array}{l}1200 \\
(750)\end{array}$ & $\begin{array}{c}410 \\
(410)\end{array}$ & $\begin{array}{l}3147 \\
(40)\end{array}$ & & & & $\begin{array}{c}4757 \\
(1200)\end{array}$ \\
\hline Namibia & & 300 & 774 & 360 & & 60 & & 1494 \\
\hline South Africa & & $\begin{array}{c}8670 \\
(8670)\end{array}$ & 260 & $\begin{array}{c}1332 \\
(1332)\end{array}$ & 130 & $\begin{array}{l}1849 \\
1849\end{array}$ & $\begin{array}{c}1649 \\
(1649)\end{array}$ & $\begin{array}{c}13890 \\
(13500)\end{array}$ \\
\hline Swaziland & & 1000 & & & $\begin{array}{c}85 \\
(85)\end{array}$ & & & $\begin{array}{l}1085 \\
(85)\end{array}$ \\
\hline Tanzania & & $\begin{array}{c}600 \\
(200)\end{array}$ & $\begin{array}{c}400 \\
(400)\end{array}$ & 1972 & $\begin{array}{c}35 \\
(35)\end{array}$ & & & $\begin{array}{l}3007 \\
(675)\end{array}$ \\
\hline Zambia & $\begin{array}{c}50 \\
(50)\end{array}$ & 300 & & $\begin{array}{c}4900 \\
(1375)\end{array}$ & & & & $\begin{array}{c}5250 \\
(1425)\end{array}$ \\
\hline Zimbabwe & & 2000 & 300 & $\begin{array}{l}1100 \\
(300)\end{array}$ & $\begin{array}{c}90 \\
(90)\end{array}$ & & & $\begin{array}{l}3490 \\
(390)\end{array}$ \\
\hline Total & $\begin{array}{c}338 \\
(198)\end{array}$ & $\begin{array}{c}17700 \\
(10820)\end{array}$ & $\begin{array}{l}2144 \\
(810)\end{array}$ & $\begin{array}{l}40590 \\
(4282)\end{array}$ & $\begin{array}{c}358 \\
(228)\end{array}$ & $\begin{array}{c}1974 \\
(1849)\end{array}$ & $\begin{array}{c}1649 \\
(1649)\end{array}$ & $\begin{array}{c}34173 \\
(19836)\end{array}$ \\
\hline
\end{tabular}

${ }^{*}$ First year of future projects range from 2010 to 2025.

due to lack of liberalisation in the energy markets and to a lesser extent lack of associated market trading tools, which would normally follow once the market is liberalised. South Africa's National Energy Regulator (NERSA) is currently running a FIT programme based on the cost of generation plus a "reasonable profit". This has given rise to interest by private companies and communities to invest in energy generation projects such as wind farms, concentrated solar power and small-medium hydro.

\subsection{Policy Development in South Africa [14]}

- According to the Electricity Regulation Act of 2006, all commercially-operated small-scale embedded generators connected to the grid are required to be licensed or registered with the National Energy Regulator of South Africa (NERSA); this includes none-or-net consumers as long as they are grid-connected.

- The development of policy in South Africa with regards to renewable energy (and distributed energy) has undergone three stages as follows: 
- Renewable Energy Finance Subsidy (REFS) 2006-2009,

- Renewable Energy Feed-In Tariff (REFIT) 2009-2011, and

- Renewable Energy Independent Power Producer Procurement Programme (REIPPPP) after 2011.

- However, the third stage REIPPPP, despite receiving accolades worldwide as having been highly successful, only covered producers with capacities greater than $5 \mathrm{MW}$ for all renewable systems and more than $1 \mathrm{MW}$ for small scale photovoltaic systems thus excluding a larger number of small scale distributed energy producers especially rooftop photovoltaic systems.

- NERSA had been in the process of preparing the small scale embedded generation regulatory framework and it was anticipated it was to complete the exercise in early 2016 according to the Department of Energy (DoE).

\subsection{Policy Development in Botswana}

\subsubsection{Overview}

- The Energy Supply Act of Botswana was amended in 2007 as a way of facilitating the participation of Independent Power Producers (IPP's) in electricity generation [16].

- Botswana Power Corporation (BPC) is the state-owned national power utility responsible for the generation, transmission and distribution of electricity in the country; it is configured on the vertically-integrated utility model; and currently there are not specific plans to unbundle the utility functions.

- BPC operates the two coal fired power plants, the $132 \mathrm{MW}$ Morupole A and the $600 \mathrm{MW}$ Morupule B, as well as the $70 \mathrm{MW}$ Matshelagabedi diesel peaking plant; it also operates the 1.3 MW grid-connected Phakalane Solar PV plant.

- The 90 MW Orapa dual fuel (gas and diesel) plant is the only IPP operated plant. It is operated by Karoo Sustainable Energy (KSE), the only IPP appointed by the BPC to date.

- Since November, 2015 the government is in the process of securing IPP' to develop an additional $300 \mathrm{MW}$ expansion of Morupule B.

- The government has also issued an Expression of Interest (EOI) for a scalable 100 MW Solar Power Plant at Jwaneng. The plant would be constructed, operated, maintained and decommissioned at the end of its economic life by an IPP.

\subsubsection{National Energy Policy for Botswana (Draft) [17]}

The draft policy expresses the overall policy goal for the energy sector as to provide reasonably priced, environmentally benign and sustainable energy services in order to foster social and economic development. Information sources for the draft policy included the following in addition to consultations with various stakeholders:

- Botswana's Vision 2016,

- National Development Plan (NDP 10), 
- Botswana Energy Master Plan (BEMP),

- Biomass Energy Strategy

In 2011, it was announced that Botswana would introduce renewable energy feed-in tariffs for electricity generation in 2012. Under this arrangement IPP's would be paid for generating electricity for the country's national grid. The size of projects under this scheme was limited to below $5 \mathrm{MW}$; all projects with capacities above $5 \mathrm{MW}$ would be implemented through power purchase agreements with the Botswana Power Corporation. The renewable energy mix was expected to also include generation from biogas and biodiesel. Companies from Mauritius, China and South Africa had shown interest in the scheme.

\section{Discussions and Conclusion}

That there is need to finding lasting solutions to the current energy crisis engulfing the entire southern African sub-region is no more a contentious issue; rather the bigger question should be what approach would provide more flexible, cost effective and more enduring results; and adoption of distributed energy systems is one model that could provide the key to unlocking the energy puzzle. Stand-alone systems have on the overall performed well in developing countries including in the rural areas in Southern Africa in sectors such as education, health and sanitation; wide spread adoption has not taken off mainly due to financial constraints; most developments have relied heavily on government and foreign aid financing. Grid integration of distributed energy resources is not without hurdles but has proven to be a more successful strategy in most industrialised energy markets.

The paper has deliberated on the benefits as well as challenges that face the full scale integration of distributed energy resources in the current conventional centralised energy systems. The paper has also indicated the three ways in which distributed energy systems can contribute to achieving a cleaner energy scenario through:

- Reduced transmission and distribution losses (and costs);

- Through improved energy efficiency by making it feasible and cost effective to adopting combined heat and power (CHP), combined cooling, heat and power (CCHP), and through incorporating low temperature thermal energy (waste energy) conversion systems; and

- Through the promotion of fuel diversity/mix thus making it attractive to harness renewables for grid-connection.

The study has noted that several changes in energy systems globally are responsible for the drive for policy developments. There has been significant renewable energy deployment in Africa but that more progress is hampered by lack of strong policy support. South Africa has scored great successes with its REIPPPP but is still lacking on support for small scale distributed energy resource deployment mechanisms [18]. Botswana is making progress with policy development but still far from achieving significant distributed energy resource deployment. 


\section{References}

[1] DNV GL Energy Report (2014) A Review of Distributed Energy Resources. Energy Advisory, Arlington, VA.

[2] Renewables (2015) Global Status Report, REN21, UNEP, 15 Rue de Milan, F-75441 ParisCEDEX09, France. http://www.ren21.net/gsr

[3] Jeremi, M. (2009) Distributed vs. Centralized Electricity Generation: Are We Witnessing a Change of Paradigm? An Introduction to Distributed Generation. Energy Track, HEC. http://www.vernimmen.net

[4] KPMG's Global Infrastructure and Projects Group Africa Team, Report (2011) Sub-Saharan Africa Power Outlook. Johannesburg, South Africa.

http://www.kpmg.com/ZA/en/IssuesAndInsights/ArticlesPublications/General-Ind ustries-Publications/Documents/

[5] Energy Technology Systems Analysis Programme (ETSAP) (2014) Technology Brief E12, Electricity Transmission and Distribution. http://www.iea-etsap.org

[6] http://www.caiso.com/Documents/Unaccounted_Energy_UFE.pdf

[7] http://www.iol.co.za/news/south-africa/kwazulu-natal/no-land-no-house-no-vote-1 .1070896

[8] http://www.mpoweruk.com/energy_efficiency.htm

[9] https://en.wikipedia.org/wiki/Cogeneration\#/media/File:Trigeneration_Cycle.jpg

[10] Baldick, R. (2002) Grid Limitations. Presentation to the President's Council of Advisors for Science and Technology, Department of Electrical and Computer Engineering, University of Texas at Austin, USA. http://users.ece.utexas.edu/ baldick/papers/PCAST.pdf

[11] Dionysio, A. (2011) Lecture Slides by Daniel Kirschen for Kirschen/Strbac Chapter 1, with edits by Leigh Tesfatsion.

[12] Critical Consumer Issues Forum (2013) Policy Considerations Related to Distributed Energy Resources. http://www.cciforum.com/.

[13] Miketa Asami (IRENA) and Merven Bruno (Energy Research Centre) (2013) Southern African Power Pool: Planning and Prospects for Renewable Energy. International Renewable Energy Agency (IRENA). http://www.irena.org

[14] Eberhard, A., et al. (2014) South Africa's Renewable Energy IPP Procurement Program-Success Factors and Lessons. (c) 2014 Public-Private Infrastructure Advisory Facility (PPIAF), 1818 H Street, NW, Washington, DC, 20433. http://www.ppiaf.org

[15] http://www.geni.org/globalenergy/library/national_energy_grid/south-africa/southa fricannationalelectricitygrid.shtml

[16] http://www.gov.bw/globalassets/mmwer/act-no--20-ammnedment-esa.pdf

[17] Mzezewa, C.T. (2009) Technical Report: National Energy Policy for Botswana-Final Draft, AECOM International Development, Gaborone, Botswana, USAID Contract No. 690-M-00-04-00309-00 (GS 10F-0277P).

[18] ClimateScope (2015) The Clean Energy Country Competitiveness Index. http://global-climatescope.org/en/region/africa/ 


\section{Abbreviations}

AC: alternating current

BEMP: Botswana Energy Master Plan

BPC: Botswana Power Corporation

CCHP: Combined Cooling, Heat and Power

CHP: Combined Heat and Power

DC: Direct Current

DE: Decentralised Energy

DER: Distributed Energy Resources

DESS: Distributed Energy Storage Systems

DMFC: Direct Methanol Fuel Cell

DisCo: Distribution Company

DoE: Department of Energy

EOI: Expression of Interest

FIT: Feed-In Tariff

ICE: Internal Combustion Engine

IEA: International Energy Agency

IPP: Independent Power Producer

KSE: Karoo Sustainable Energy

$\mathrm{kW}$ : kilowatt

MCFC: Molten Carbon Fuel Cell

MW: MegaWatt

NDP: National Development Plan

NERSA: National Energy Regulator of South Africa

NPU: National Power Utility

PAFC: Phosphoric Acid Fuel Cell

PEMFC: Proton Exchange Membrane Fuel Cell

REFIT: Renewable Energy Feed-In Tariff

REFS: Renewable Energy Finance Subsidy

REIPPPP: Renewable Energy Independent Power Producer Procurement Programme

SAPP: Southern African Power Pool

SOFC: Solid Oxide Fuel Cell

UPS: Uninterrupted Power Supply

W: Watt 
Submit or recommend next manuscript to SCIRP and we will provide best service for you:

Accepting pre-submission inquiries through Email, Facebook, LinkedIn, Twitter, etc. A wide selection of journals (inclusive of 9 subjects, more than 200 journals)

Providing 24-hour high-quality service

User-friendly online submission system

Fair and swift peer-review system

Efficient typesetting and proofreading procedure

Display of the result of downloads and visits, as well as the number of cited articles Maximum dissemination of your research work

Submit your manuscript at: http://papersubmission.scirp.org/

Or contact jsbs@scirp.org 